\title{
PENENTUAN HARGA JUAL STRATEJIK TERHADAP PRODUK DENGAN STRATEGI BIAYA RENDAH DAN DIFERENSIASI ${ }^{1}$
}

\author{
Diana Zuhroh \\ Universitas Merdeka Malang \\ diana.zuhroh@unmer.ac.id \\ Cindy Pratiwi \\ Universitas Merdeka Malang \\ cindy.pratiwi333@yahoo.co.id
}

\begin{abstract}
Determination of strategic pricing is one of the business strategy that focuses on competitive pricing that give benefit for the company who would faces competitor in competitive product. Companies that use strategic pricing will be able to win the global competition because it has some advantages in many aspects that are less taken into account in determining the strategic price of conventional. With strategic pricing, the company is expected to improve their competitiveness in the market. The objective of this study is to identify and analyze the strategic process of determining the selling price or strategic pricing based on cost lifecycle and the position of product in the products lifecycle. This will be manifested in the use of appropriate business strategy for each product and the calculation of the research costs, design costs, production costs, mark-ups that are tailored to target consumers to produce strategic pricing of products that can be competitive in price competition.
\end{abstract}

Keywords: strategic pricing, product lifecycle, cost lifecycle.

\begin{abstract}
Abstraksi
Penentuan harga strategis merupakan salah satu strategi bisnis yang berfokus pada harga yang kompetitif yang memberikan manfaat bagi perusahaan yang akan menghadapi pesaing dalam produk yang kompetitif. Perusahaan yang menggunakan harga strategis akan dapat memenangkan persaingan global karena memiliki beberapa keuntungan dalam banyak aspek yang kurang diperhitungkan dalam menentukan harga strategis. Dengan harga strategis, perusahaan diharapkan untuk meningkatkan daya saing. Tujuan dari penelitian ini adalah untuk mengidentifikasi dan menganalisis proses strategis penentuan harga jual atau harga strategis berdasarkan biaya siklus hidup produk dan posisi produk dalam siklus hidup produk. Ini akan diwujudkan dalam penggunaan strategi bisnis yang tepat untuk setiap produk dan perhitungan biaya penelitian, biaya desain, biaya produksi, mark-up yang disesuaikan dengan target konsumen untuk menghasilkan harga strategis dari produk yang bisa bersaing di kompetisi harga .
\end{abstract}

Kata kunci: strategi penentuan harga, siklus hidup produk, biaya siklus hidup produk

\section{PENDAHULUAY}

Salah satu dampak langsung dari penerapan Masyarakat Ekonomi ASEAN (MEA) adalah

\footnotetext{
1 Artikel ini telah dipresentasikan dalam Konferensi Regional Akuntansi II di Malang pada tanggal 29-30 April 2015. Penulis mengucapkan terimakasih atas saran dan masukan dari partisipan konferensi untuk penyempurnaan artikel ini.
}

bebasnya bea masuk atau tarif bagi produkproduk dari Negara ASEAN yang akan masuk ke Indonesia. Hal tersebut dikhawatirkan akan mempersulit perusahaan domestik untuk bersaing dengan produk-produk impor, oleh karena itu perusahaan harus lebih siap menghadapi persaingan yang ketat. Salah satu cara yang dapat dilakukan oleh perusahaan dalam menghadapi permasalahan ini adalah 
melalui penentuan harga jual yang kompetitif. Harga jual yang kompetitif dapat diwujudkan dengan menetapkan harga jual produk yang mampu menjadi pembanding bagi pembeli secara luas.

Perhitungan harga produksi sebagai dasar penentuan harga jual produk belum cukup untuk dapat memenangkan pasar dengan pesaing (Hogan and Nagle, 2005). Dengan kata lainperusahaan tidak dapat hanya menentukan harga jual dengan memperhitungkan harga produksinya saja, namun juga harus mempertimbangkan berbagai faktor yang mempengaruhi harga jual. Hal ini harus menjadi pertimbangan bagi manajemen karena bisnis yang menggunakan harga sebagai alat strategis akan menghasilkan lebih banyak laba dibandingkan dengan bisnis yang hanya membiarkan biaya atau pasar menentukan penetapan harga mereka. (Kotler, et al. 2009:77).

Secara historis, salah satu pendekatan harga jual yang paling banyak digunakan oleh perusahaan adalah penentuan harga jual berbasis kos (Cost-plus Pricing) atau yang disebut juga sebagai Cost-driven Pricing. Kelemahan utama pendekatan ini adalah: penentuan biaya termasuk penggunaan alokasi beberapa jenis biaya menggunakan satuan unit sebagai dasar yang berakibat kos produk kurang akurat (Micu and Micu, 2006). Oleh karena itu dalam perkembangan selanjutnya perusahaan mulai menggunakan pendekatan lain, misalnya customer-driven pricing (yang dianggap lebih mencerminkan kondisi pasar) dan competition-driven pricing atau strategic pricing (yang dianggap lebih stratejik) sehingga memungkinkan perusahaan mampu memenangkan persaingan. Strategic pricing atau penetapan harga jual stratejik merupakan penetapan harga yang bertujuan memperbaiki profitabilitas dengan menekankan pada peningkatan value bagi konsumen dan tidak sekedar peningkatan volume penjualan (Strategic Edge LLC, 2008).

Berbeda dengan penetapan harga jual konvensional yang menekankan pada biaya produksi historis, penetapan harga jual strategis memerlukan informasi penting lainnya yang meliputi: reaksi harga pesaing, elastisitas harga (perubahan permintaan jika terjadi perubahan harga), pertumbuhan pasar dan beberapa perimbangan lainnya. Dengan kata lain, penetapan harga jual strategis memerlukan informasi pelanggan, pesaing dan biaya (Lansiluoto, et al, 2007). Oleh karena itu metode penentuan harga jual strategis merupakan pricing strategically, yang berarti, untuk memenangkan persaingan, penentuan harga senantiasa dikaitkan dengan strategi yang dipilih oleh perusahaan (Micu and Micu, 2006).

Menurut Blocher et al. (2010, 567), penentuan harga jual strategis membantu manajemen dalam menentukan harga produk atau jasa yang didasarkan pada daur hidup biaya, atau berdasarkan pada posisinya di sepanjang daur hidup produk. Bagi manajemen aktivitas ini sangat kompleks karena berkaitan dengan analisis yang mengkaitkan isu strategi bersaing dan informasi biaya. Ini berarti, harga tidak bersifat statis namun sangat dinamis karena harus terus menerus disesuaikan dengan faktor-faktor ekasternal, terutama konsumen dan persaingan dengan produk kompetitor.

Produk dengan strategi biaya rendah (low cost) menekankan pada efisiensi biaya menyeluruh agar dapat menekan keseluruhan biaya sehingga dapat menetapkan harga jual yang rendah. Sebaliknya, produk dengan strategi diferensiasi lebih leluasa dalam menentukan harga jual produk dengan beberapa alternatif. Sebagaimana dikemukakan oleh Blocher et al (2010, 564), cara yang dapat dipilih adalah: pertama, dengan menetapkan harga jual yang cukup tinggi, kedua menetapkan harga lebih rendah untuk meraih pangsa pasar yang lebih besar, dan ketiga dengan membina hubungan atau relasi yang baik dengan pelanggan. Ini berarti, informasi harga pokok (cost) historis merupakan tahap paling awal penentuan harga dari serangkaian proses yang kompleks tersebut.

Penelitian ini merupakan studi kasus di PG $\mathrm{X}$ yang memproduksi, diantaranya adalah RG dan RGLF (lampiran). Produk-produk tersebut tidak langsung dijual kepada konsumen akhir melainkan dikirim ke distributor, untuk selanjutnya disalurkan ke pasar. Produk RG merupakan produk gula tebu yang telah diluncurkan lebih dari 3 (tiga) tahun yang lalu dan telah memiliki pesaing yang cukup banyak di pasaran. Produk RGLF merupakan produk gula rendah kalori dengan konsumen sangat terbatas yaitu konsumen penderita diabetes atau konsumen menengah keatas yang sadar terhadap kesehatan. 
Harga merupakan salah satu faktor yang masih menimbulkan masalah bagi perusahaan mengingat harga pesaing yang makin bervariasi. Selain itu kemasan produk pesaing yang lebih menarik serta sistem pemasaran yang dinilai telah lebih baik menjadikan produk PG $\mathrm{X}$ ini harus bersaing sangat ketat di pasaran. Untuk itu berbagai upaya perlu dilakukan agar produk-produk yang dihasilkan oleh PG X ini mampu bersaing dengan -produk pesaing yang makin menjamur di pasar.

Selama ini PG X dalam menentukan harga jual menggunakan pendekatan full cost plus margin. Dalam rangka merespon makin ketatnya persaingan produk gula, penelitian ini dilakukan dengan tujuan memberikan masukan dalam memperbaiki proses penentuan harga jual untuk meningkatkan keunggulan bersaing produk melalui penentuan harga yang kompetitif. Pendekatan yang diusulkan adalah penentuan harga jual stratejik berbasis daur hidup produk dan biaya, yang oleh beberapa peneliti dinilai lebih tepat digunakan dalam lingkungan bisnis dengan persaingan yang sangat ketat. Dari beberapa hal yang dikemukakan diatas maka peneliti ingin melakukan penelitian mengenai bagaimanakah implementasi penentuan harga jual strategis berbasis daur hidup produk dan daur hidup biaya untuk produk RG dan RGLF. Hasil penelitian ini diharapkan bermanfaat bagi perusahaan yang merupakan produsen $\mathrm{RG}$ dan RGLF, termasuk bagi perusahaan lain yang memproduksi produk dengan persaingan tajam di pasaran. Disamping itu hasil penelitian ini diharapkan juga bermanfaat bagi peneliti selanjutnya terutama dalam pengembangan teori akuntansi manajemen pada umumnya.

\section{KAJIAN PUSTAKA}

\section{Strategi Bisnis}

Strategi bisnis adalah serangkaian komitmen yang terpadu dan terkoordinasi dan segala tindakan yang digunakan perusahaan untuk mendapatkan keuntungan kompetitif dengan memanfaatkan kompetensi inti di pasar produk tertentu. (Ireland, et al. 2009:125). Beberapa tipe strategi bisnis untuk membangun dan mempertahankan keunggulan perusahaan disajikan dalam Gambar 1.

Strategi diferensiasi adalah upaya mendiferensiasikan produk atau jasa yang ditawarkan perusahaan dengan menciptakan sesuatu yang baru yang dirasakan oleh keseluruhan industri sebagai hal yang unik atau khas dalam hal: rancangan (desain), merk, kualitas, teknologi, layanan konsumen, jaringan distribusi dan dimensi-dimensi lainnya (Porter, 1993:33). Keunikan produk yang dikedepankan ini memungkinkan suatu perusahaan menarik minat sebesar-besarnya dari konsumen potensialnya. Keunggulannya yaitu focused differentiation memiliki pelanggan setia yang tidak sensitif dengan kenaikan atau penurunan harga produk karena produk yang dihasilkan merupakan produk unik yang secara khusus ditujukan dan terintegrasi untuk target konsumen tertentu.

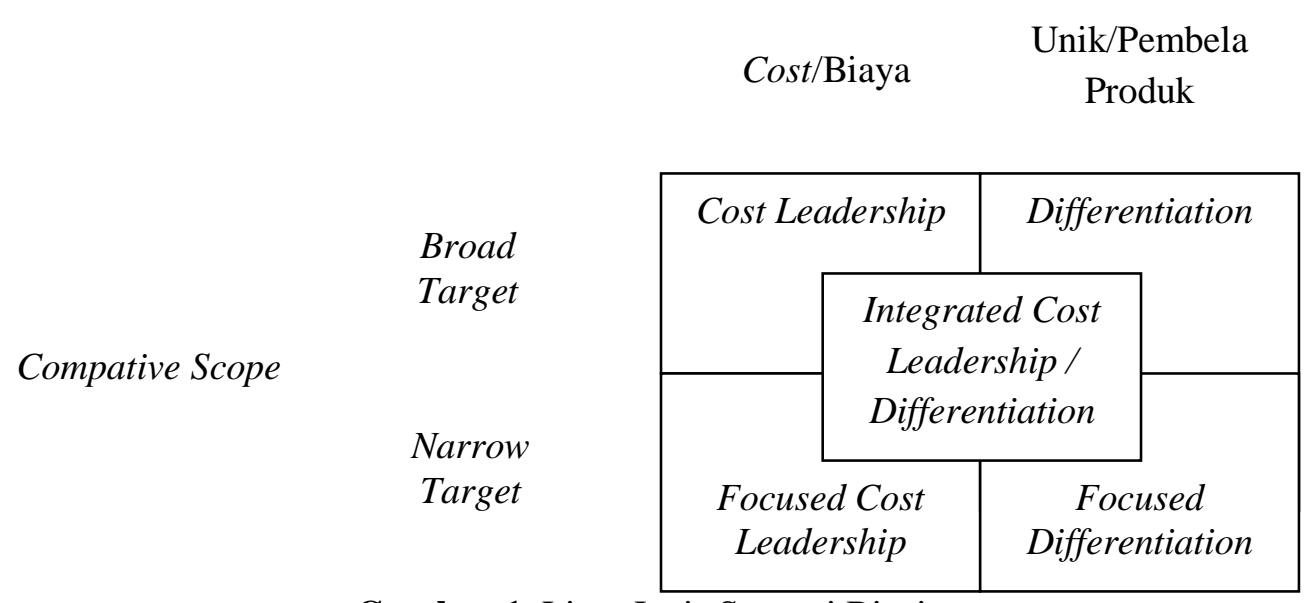

Gambar 1. Lima Jenis Strategi Bisnis

Sumber: Ireland, 2009:131 
Strategi keunggulan biaya rendah (low cost) adalah upaya memenangkan persaingan melalui keunggulan biaya rendah dalam industri dengan menciptakan seperangkat kebijakan yang ditujukan untuk mencapai efisiensi dibandingkan pesaing (Porter, 1993:32). Dalam Dudung (2012), strategi ini memiliki dua macam strategi turunannya, yaitu produk dijual dalam rata-rata harga industri untuk meraih keuntungan yang lebih besar dari pesaing lain dan produk dijual dibawah rata-rata harga industri untuk meraih market-share yang lebih luas. Keunggulan menggunakan cost leadership adalah pesaing akan ragu untuk bersaing dengan harga minimum, terutama sebelum mengevaluasi potensi hasil kompetisi pasar dan cost leader beroperasi dengan margin lebih besar dibandingkan dengan pesaing.

\section{Penentuan Harga Jual Stratejik}

Harga merupakan salah satu unsur yang mempengaruhi kegiatan-kegiatan perusahaan yang berfungsi menciptakan keunggulan kompetitif bagi perusahaan (Suwarni,2013). Pemahaman terhadap kebutuhan dan keinginan serta selera konsumen sangat penting dipahami oleh manajer agar perusahaan dapat memberikan "value" bagi konsumen, dan selanjutnya dapat dijadikan sebagai dasar dalam menetapkan harga yang sebanding dengan value tersebut (Dolan and Gourville, 2009). Strategic pricing atau penentuan harga jual stratejik adalah "...the coordination of interrelated marketing, competitive, and financial decisions to set prices profitably" (Micu and Micu, 2006). Perbedaan utama penetapan harga jual tradisional dengan penetapan harga jual stratejik adalah respon atau reaksi manajemen terhadap kondisi pasar. Ini berarti penetapan harga jual stratejik memerlukan keterkaitan atau hubungan antara faktor pemasaran dengan keuangan. Penetapan harga jual stratejik didasarkan pada konsepkonsep berikut: 1) Dalam era persaingan yang ditandai oleh makin homogennya produk, konsumen hanya bersedia membayar untuk barang yang memberinya nilai atau manfaat yang optimal. 2) Perusahaan perlu memahami segmen pasar untuk produknya. Pemahaman tersebut harus dijadikan dasar bagi perusahaan untuk menetapkan harga yang seimbang dengan kebutuhan konsumen di tengah dinamika persaingan (Strategic Edge, LLC, 2008).

Sementara itu menurut Kiokue (2012), tujuan dari strategic pricing adalah: 1) Tujuan berorientasi pada Laba atau maksimisasi laba. 2) Tujuan berorientasi pada Volume atau volume pricing objective. Harga ditetapkan sedemikian rupa agar dapat mencapai target volume penjualan atau pangsa pasar. 3) Tujuan berorientasi pada citra, perusahaan menetapkan harga tinggi untuk membentuk atau mempertahankan citra prestisius. Sementara itu harga rendah dapat digunakan untuk membentuk citra nilai tertentu (image of value). 4) Tujuan beriorientasi pada harga. Tujuan ini biasanya digunakan oleh perusahaan yang memiliki konsumen yang sensitive terhadap harga.

\section{Penentuan Harga Jual Stratejiik berdasar- kan Cost Lifecycle dan Product Lifecycle}

Menurut Blocher et al, (2010, 546), strategic pricing adalah proses penentuan harga jual yang mempertimbangkan dua faktor yaitu cost lifecycle dan product lifecycle. Cost lifecycle adalah serangkaian aktivitas dalam organisasi yang dimulai dari aktivitas riset dan pengembangan, desain, produksi, pemasaran/distribusi dan layanan konsumen (Gambar 2).

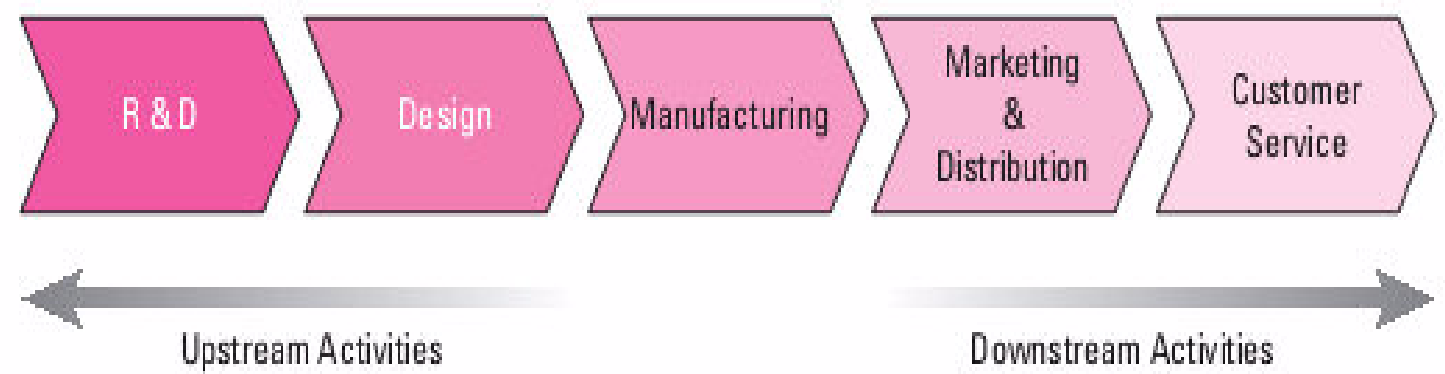

Gambar 2. Cost Lifecycle

Sumber: Blocher et al 2010: 564 


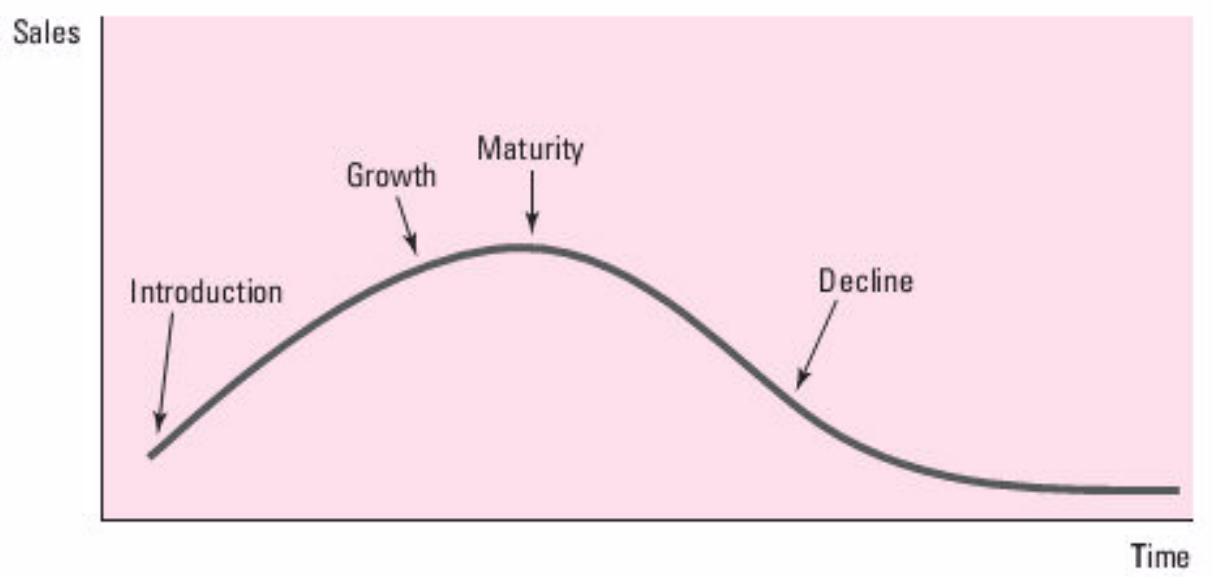

Gambar 3. Sales Lifecycle.

Sumber: Blocher et al 2010:545

Berdasarkan gambar tersebut, upstream activities merupakan serangkaian aktivitas yang terdiri dari aktivitas riset/pengembangan dan desain, sedangkan downstream activities meliputi aktivitas marketing/distribution dan layanan konsumen. Sedangkan life-cycle costing adalah metode yang digunakan untuk mengidentifikasi dan memonitor kos produk di sepanjang cost lifecycle. Sistem tradisional hanya memperhitungkan biaya pada tahap ke tiga yaitu tahap produksi sehingga hanya memperhitungkan biaya produksi yang terdiri dari biaya bahan baku, tenaga kerja langsung dan biaya overhead pabrik. Kelemahan utama dalan penetapan harga jual tradisional tersebut adalah menggunakan dasar unit yang diproduksi dan dalam pembebanan alokasi biaya overhead yang pada umumnya menggunakan jam tenaga kerja langsung sebagai dasar pembebanan (Hansen and Mowen, 2007:48).

Sementara itu, menurut Blocher et al, (2010, 564), sales lifecycle adalah daur hidup produk yang dimulai dari tahap perkenalan, pertumbuhan, kematangan dan penurunan dan selanjutnya ditarik dari pasar, sebagaimana tampak dalam Gambar 3. Berdasarkan gambar tersebut, pada saat perkenalan produk baru, volume penjualan umumnya masih relatif kecil dan akan mulai meningkat pada tahap pertumbuhan (growth). Terhadap produk yang pengembangannya memerlukan biaya penelitian dan pengembangan yang tinggi, sampai dengan tahap ini umumnya perusahaan belum dapat menutup biaya riset dan pengembangan. Selanjutnya peningkatan akan terus berlang- sung dan volume penjualan tertinggi dicapai pada tahap maturity, dan pada tahap ini perusahaan dapat menetapkan harga jual lebih tinggi untuk menutup biaya riset dan pengembangan. Hal ini dapat dimungkinkan mengingat umumnya produk pesaing masih belum menjadi ancaman serius. Seiring dengan makin banyaknya produk pesaing yang mungkin membanjiri pasaran, produk akan mulai memasuki masa kejenuhan yang ditandai dengan makin menurunnya volume penjualan. Pada tahap ini umumnya manajemen mulai menurunkan harga jual agar penurunan volume penjualan tidak sampai member dampak kerugian.

Secara umum, kebijakan yang perlu diambil oleh manajemen dalam rangka implementasi penentuan harga jual stratejik menurut Blocher et al (2010:564) adalah sebagai berikut: 1) 1. Terhadap produk dengan strategi biaya rendah, penentuan harga jual didasarkan pada cost yang menekankan efisiensi biaya. 2) Terhadap produk dengan strategi diferensiasi, penentuan harga jual dapat dilakukan dengan kebijakan sebagai berikut: a) Harga ditetapkan tinggi untuk suatu kelompok konsumen tertentu, dan harga yang lebih rendah untuk kelompok lainnya (skimming). b) Harga ditetapkan rendah untuk meraih pangsa pasar yang lebih besar (penetrasi). c) Dalam rangka membangun hubungan khusus jangka panjang dengan konsumen, harga yang ditetapkan disesuaikan dengan kebutuhan tertentu konsumen (value-pricing).

Sementara itu, dalam penentuan harga jual stratejik yang mendasarkan pada product 
lifecycle manajemen harus memperhatikan posisi produk harga jual ditetapkan sesuai dengan posisinya dalam daur hidup tersebut, dengan rincian sebagai berikut (Blocher et al, 2010:566): a) Pada tahap pengenalan (introduction). Pada tahap ini harga sebaiknya ditetapkan lebih tinggi untuk menutup biaya desian, riset/pengembangan dan biaya pemasaran. Harga tinggi dapat dimungkinkan karena persaingan dianggap masih belum terlalu tajam. b) Pada tahap pertumbuhan (growth). Meskipun volume penjualan berangsur meningkat, pada tahap ini persaingan juga mulai meningkat karena produk sejenis di pasar mulai banyak sehingga harga menjadi sangat bersaing. Oleh karena itu harga masih harus ditetapkan tinggi. c) Pada tahap kematangan (maturity). Pada tahap ini penjulan masih terus meningkat meskipun makin lambat. Harga mengikuti kompetitor, dengan kata lain, perusahaan mulai menerapkan kebijakan price taker, tidak lagi sebagai price setter. d) Pada tahap penurunan (decline). Oleh karena pada tahap ini penjualan makin menurun, demikian juga harga juga mulai diturunkan maka untuk menghindari kerugian, manajemen harus fokus pada efisiensi biaya-biaya di downstream dan upstream.

Keuntungan penentuan harga jual stratejik ini menurut Blocher et al $(2010,564)$ adalah "the life-cycle approach has the advantage that all costs are included, so that the markup percentage can be directly tied to a desired level of profit..."

\section{METODE PENELITIAN}

Penelitian ini adalah studi kasus di PG X. Data yang diperlukan adalah data primer yang dikumpulkan melalui wawancara dan dokumentasi. Wawancara dilakukan untuk mendapatkan data yang berkaitan dengan penentuan margin, kebijakan pemasaran dan distribusi, dan kebijakan yang dapat dijadikan sebagai dasar dalam menentukan strategi bersaing yang dipilih untuk masing-asing produk. Sedangkan dokumentasi digunakan untuk mendapatkan data Laporan Rugi Laba untuk tahun yang berakhir pada tanggal 31 Desember 2013. Analisis data menggunakan metode deskriptif kuantitatif, dengan tahap- tahap sebagai berikut: 1) Analisis biaya-biaya downstream dan upstream dalam cost lifecycle. 2) Menghitung harga jual stratejik dengan rumus (Blocher et al 2010,565):

$$
\begin{aligned}
& \text { Harga }= \\
& \frac{\text { Total Biaya life-cycle }}{(1-\text { Persentase Margin yang diinginkan })}
\end{aligned}
$$

3) Menganilisis posisi masing-masing produk dalam product lifecycle, karakteristik konsumen masing-masing produk, dan strategi bersaing yang sebaiknya dijalankan oleh manajemen. 4) Pembahasan hasil. Berdasarkan analisis pada tahap 1,2 dan 3, dilakukan pembahasan berkaitan dengan kebijakan harga jual stratejik yang sebaiknya diambil oleh manajemen.

\section{HASIL ANALISIS}

Sesuai dengan tahap-tahap analisis data sebagaimana dijelaskan sebelumnya, berikut ini disajikan data dan hasil analisis data.

\section{Analisis biaya-biaya downstream dan up- stream dalam cost lifecycle}

Berdasarkan wawancara dengan manajer keuangan, biaya-biaya downstream dan upstream dalam cost lifecycle serta margin yang dibebankan kepada produk disajikan dalam Tabel 1. Berdasarkan tabel tersebut, komponen biaya upstream dan downstream dalam lifecycle cost meliputi: biaya Riset dan Pengembangan (R\&D), desain, manufacturing dan marketing \& distribution. Margin untuk produk RG tidak lebih dari 5\% karena berkaitan dengan regulasi pemerintah di bidang gula, sedangkan untuk RGLF dimungkinkan sampai dengan $20 \%$ karena produk ini tidak termasuk produk yang harganya harus ditetapkan berdasarkan peraturan pemerintah. Berdasaran perhitungan biaya yang diperoleh dari Laporan Laba-Rugi Untuk Tahun Yang Berakhir Pada 31 Desember 2013 diperoleh data sebagaimana disajikan dalam Tabel 2.

Dari tabel tersebut tampak, untuk produk RG, total biaya yang dihitung berdasarkan cost lifecycle adalah Rp.12.953,36 untuk produk RG dan Rp.27.863,67/kg untuk produk RGLF/kg. 
Tabel 1. Komponen Biaya Upstream dan Downstream Dalam Lifecycle Cost

\begin{tabular}{|c|c|c|c|c|c|}
\hline Upstream & $R \& D$ & Desain & Produksi & $\begin{array}{l}\text { Pemasaran dan } \\
\text { Distribusi }\end{array}$ & $\begin{array}{l}\text { Mark Up } \\
\text { (margin) }\end{array}$ \\
\hline \multicolumn{6}{|l|}{ Produk Cost } \\
\hline RG & $\begin{array}{l}\text { Produk dan } \\
\text { Konsumen }\end{array}$ & $\begin{array}{l}\text { Desain proses, } \\
\text { kemasan dan } \\
\text { distribusi produk. }\end{array}$ & $\begin{array}{l}\text { Bahan Baku, } \\
\text { penolong, TKL, } \\
\text { Overhead }\end{array}$ & $\begin{array}{l}\text { Biaya iklan, } \\
\text { penjualan, Gaji } \\
\text { Pegawai, dsb }\end{array}$ & $3 \%-5 \%$ \\
\hline RGLF & $\begin{array}{l}\text { Produk, } \\
\text { Konsumen, } \\
\text { Distribusi. }\end{array}$ & $\begin{array}{l}\text { Desain proses, } \\
\text { kemasan dan } \\
\text { distribusi produk. }\end{array}$ & $\begin{array}{l}\text { Bahan Baku, } \\
\text { penolong, TKL, } \\
\text { Overhead. }\end{array}$ & $\begin{array}{l}\text { Biaya iklan, } \\
\text { penjualan, Gaji } \\
\text { Pegawai, dsb }\end{array}$ & $\begin{array}{l}15 \%- \\
20 \%\end{array}$ \\
\hline
\end{tabular}

Tabel 2. Total biaya per unit berdasarkan Life-cycle Product Pada Produk RG dan Produk RGLF

\begin{tabular}{|c|c|c|}
\hline Keterangan & Produk RG & Produk RGLF \\
\hline Biaya R \& D & Rp 1.295,33 & $\operatorname{Rp} 4.179,55$ \\
\hline Biaya Desain & Rp 1.156,08 & Rp 2.486,83 \\
\hline Biaya pemasaran \& distribusi & Rp 204,01 & $\operatorname{Rp} 438,85$ \\
\hline Biaya Produksi & Rp 10.297,94 & Rp 20.758,44 \\
\hline TOTAL cost of Life-cycle Product / Kg & Rp 12.953,36 & $\operatorname{Rp} 27.863 .67$ \\
\hline
\end{tabular}

Sumber: Laporan Laba-Rugi Untuk Tahun Yang Berakhir Tanggal 31 Desember 2013 PG X, diolah.

Tabel 3. Perbandingan Harga Pokok (Cost) Masing-masing Produk Raja Gula

\begin{tabular}{ccc}
\hline Jenis Produk & Strategic Pricing & $\begin{array}{c}\text { Harga jual produk kepada } \\
\text { distributor selama ini }\end{array}$ \\
\hline Produk RG & Rp 13.353,97 & Rp 13.900 \\
Produk RGLF & Rp 32.780,78 & Rp 34.800 \\
\hline
\end{tabular}

\section{Menghitung harga jual stratejik}

Dari perhitungan harga jual stratejik menggunakan rumus (1) diperoleh harga jual stratejik, berikut perbandingan dengan harga jual ke distributor dan harga jual di pasar untuk masing-masing produk. Margin yang digunakan adalah 3\% untuk produk RG dan 15\% untuk produk RGLF. Hasil perhitungan disajikan dalam Tabel 3.

Dari tabel tersebut dapat dilihat bahwa hasil perhitungan harga jual stratejik sebelum ditambah margin adalah Rp.13.353,97 untuk produk RG dan sebesar Rp. 32.780,78 untuk produk RGLF. Sedangkan harga jual produk kepada distributor selama ini adalah Rp.13.900 untuk RG dan Rp.34.800 untuk produk RGLF. Harga tersebut sudah termasuk margin yang ditetapkan sesuai dengan peraturan pemerintah.

\section{Menganilisis karakteristik konsumen masing-masing produk, strategi bersaing yang sebaiknya dijalankan oleh manajemen dan posisinya masing-masing dalam product lifecycle}

Karakteristik konsumen masing-masing produk adalah sebagai berikut:

Produk RG.

Target konsumen produk ini merupakan masyarakat umum untuk penggunaan seharihari. Bahan baku produk merupakan tebu murni $100 \%$ yang apabila digunakan terus-menurus dapat mengakibatkan diabetes.

Konsumen produk RG merupakan konsumen yang sensitif dengan harga, artinya apabila terdapat kenaikan harga meskipun kecil akan menyebabkan konsumen berpindah ke produk lain (misalnya merk Gulaku), atau gula curah tanpa merk yang harganya justru jauh lebih murah. Disamping itu margin yang dibebankan terhadap produk ini juga harus mengikuti peraturan pemerintah. Oleh karena itu manajemen harus benar-benar memperhitungkan hal ini agar konsumen RG tetap loyal.

Dalam rangka menarik konsumen yang lebih besar, produsen produk ini cenderung memasang harga murah atau mengadakan diskon di supermarket atau minimarket pada 
saat-saat tertentu (misalnya: weekend atau hari besar, atau menjelang hari raya keagamaan).

\section{Produk RGLF}

Konsumen produk ini adalah kelompok tertentu dari kelas menengah ke atas yang memiliki kebiasaan sehat dalam mengkonsumsi makanan sehari-hari.Konsumen produk ini merupakan konsumen yang tidak sensitif dengan perubahan harga. Artinya, apabila mereka telah cocok atau bahkan loyal, tidak mudah berpindah ke produk lain. Supermarket atau minimarket kurang tertarik mengadakan diskon pada saat-saat tertentu terhadap produk ini sehingga intensitas perang harga di pasaran tidak terlalu tajam.

Strategi yang seharusnya dijalankan manajemen terhadap masing-masing produk. Berdasarkan analisis konsumen tersebut maka strategi yang sesuai untuk produk RG adalah strategi cost leadership atau low cost agar dapat menyaingi produk-produk pesaing melalui penetapan harga yang lebih murah. Sedangkan untuk produk RGLF menggunakan strategi bisnis focused differentiation. Pilihan strategi ini dinilai sebagai strategi yang tepat untuk menjaga kepercayaan dan loyalitas konsumen sehingga konsumen tidak mudah berpindah ke produk pesaing.

Posisi masing-masing produk dalam product lifecycle.

Produk RG telah diluncurkan lebih dari 3 (tiga) tahun yang lalu, sedangkan produk RGLF baru diluncurkan selama satu tahun. Berdasarkan waktu (lamanya) produk berada di pasaran dan kondisi persaingannya serta dikaitkan dengan karakteristik persaingan dalam konsep product lifecycle, maka dapat disimpulkan bahwa: posisi produk RG telah berada dalam phase maturity (kematangan), sedangkan produk RGLF berada pada phase pertumbuhan (growth).

\section{PEMBAHASAN}

Berdasarkan analisis tersebut di atas maka penentuan harga jual stratejik terhadap masingmasing produk adalah sebagai berikut: 1) Produk RG. Oleh karena posisi produk tersebut dalam product licycle telah berada dalam phase maturity dan menggunakan strategi Low Cost, maka PG X sebaiknya menetapkan harga dengan margin dibawah 5\% (margin maksimal yang diperbolehkan oleh pemerintah). Dengan margin yang tidak terlalu tinggi, dimungkinkan bagi produk ini untuk dijual dengan harga lebih murah daripada produk pesaing. Agar PG X dapat memperoleh keuntungan lebih tinggi meskipun dengan margin yang tidak tinggi, maka manajemen PG $\mathrm{X}$ harus mulai merencanakan meningkatkan efisiensi menyeluruh untuk menekan biaya. Untuk itu manajemen harus melakukan kajian menyeluruh terhadap aktivitas di sepanjang product lifecycle dan selanjutnya melakukan evaluasi aktivitas-aktivitas yang bernilai tambah dan tidak. Dengan mengurangi bahkan menghilangkan aktivitas tidak bernilai tambah, manajemen akan dapat meningkatkan efisiensi sehingga harga jual dapat ditetapkan lebih murah dari pada produk pesaing. 2) Produk RGLF. Indonesia adalah Negara dengan penderita diabetes No. 5 di dunia dengan jumlah penderita mencapai 9 juta lebih, dimana $70 \%$ penderitanya tidak sadar telah mengidap penyakit tersebut (www.tempo.com). Akhirakhir ini kampanye mengurangi penderita diabetes ini telah mulai diarahkan pada kaum muda sebagai bagian dari tindakan preventif. Ini berarti produk gula rendah kalori memiliki prospek bisnis yang cukup baik. Kondisi ini sebaiknya dimanfaatkan oleh PG $\mathrm{X}$ untuk memantapkan produk RGLF di pasar melalui penetapan harga jual yang kompetitif, sekaligus memberikan laba yang optimal bagi perusahaan. Dengan mempertimbangkan posisi produk yang berada dalam phase pertumbuhan (growth) dalam product lifecycle dan strategi bisnis focused differentiation untuk produk ini, maka beberapa kebijakan yang dapat dijalankan adalah: a) Meskipun dimungkinkan bagi perusahaan menggunakan margin lebih tinggi dari $15 \%$ namun karena produk RGLF ini merupakan produk gula rendah kalori yang baru diluncurkan di pasar, maka sebaiknya manajemen tidak menetapkan harga yang terlalu tinggi dengan menggunakan margin maksimal. Hal ini disebabkan karena produk RGLF masih berada pada tahap pengenalan sehingga masih perlu dilakukan promosi dengan harga yang lebih rendah dibanding produk sejenis. Selain itu dengan harga lebih rendah diharapkan konsumen mengenal dan mengetahui dahulu produk RGLF. Setelah 
mengenal, diharapkan konsumen akan terus menggunakan dan selanjutnya diharapkan akan meningkat menjadi loyalis terhadap produk tersebut. b) Agar harga yang ditetapkan tidak memberi kesan "murahan" dibandingkan dengan produk gula rendah kalori lainnya, salah satu cara yang dapat dilakukan adalah dengan menciptakan hubungan yang baik dengan konsumen agar kepercayaan kepada produk makin meningkat. Hubungan baik tersebut dapat dibangun melalui aktivitas promosi dan pendekatan konsumen lainnya, misalnya program pemeriksaan kadar gula darah gratis, atau mengadakan seminar yang atau kegiatan lain dengan tema yang berkaitan dengan kesehatan. Dengan cara ini diharapkan konsumen akan tetap loyal meskipun terdapat kemungkinan pesaing menurunkan harga jualnya.

\section{PENUTUP}

Berdasarkan analisis hasil studi yang disajikan pada bagian sebelumnya, berikut ini adalah: 1) Produk RG dan RGLF yang diproduksi oleh PG $X$ merupakan produk yang dipasarkan menggunakan strategi yang berbeda, dimana RG menggunakan strategi Biaya Rendah (Low Cost), sedangkan RGLF menggunakan strategi focused differentiation. 2) Dalam rangka memenangkan persaingan dengan strategi yang berbeda, penentuan harga jual menggunakan pendekatan stratejik berdasarkan cost lifecycle dan product lifecycle dinilai lebih tepat. 3) Produk RG dengan strategi Low Cost dan berada pada phase maturity, sebaiknya harga jual stratejik adalah: margin rendah. Untuk menjaga profitabilitas untuk produk ini sebaiknya manajemen melakukan efisiensi untuk menekan cost. 4) Produk RGLF dengan strategi focused differentiation dan berada pada phase tumbuh (growth), harga dapat ditentukan dengan margin yang tinggi. Untuk menghindari berpindahnya konsumen ke produk lain, strategi menjalin relasi/hubungan yang baik dengan konsumen dapat dilakukan.

Keterbatasan penelitian ini terutama pada keakuratan data biaya dalam Laporan Laba Rugi. Hal ini disebabkan oleh karena peneliti tidak mendapatkan data yang berkaitan dengan metode pembebanan biaya dan alokasi biaya overhead. Untuk penelitian selanjutnya sebaiknya dilakukan terhadap produk yang harganya tidak harus ditetapkan sesuai dengan peraturan pemerintah. Disamping itu perlu pula dilakukan metode survey menggunakan kuesioner untuk mendapatkan bukti empiris yang dapat digunakan untuk membuat generalisasi. Produk yang dijadikan obyek penelitian dibedakan berdasarkan: strategi bersaing (low cost dan diferensiasi), komposisi biaya downstream dan upstream dan posisi produk dalam product lifecycle.

\section{DAFTAR PUSTAKA}

Blocher. Stout. Cokins. 2010. Cost Management: A Strategic Emphasis, fifth edition, McGraw Hill Companies, 1221 Avenue of Americas, New York, NY, 10020.

Dolan and Gourville and John Gourville, 2009, Principle of Pricing, www.hbsp.harvard.edu.

Dudung, Alberto. 2012. Strategi Cost Leadership (Biaya Rendah) Generic Strategy M. Porter. Artikel. Fakultas Ekonomi, Universitas Pattimura.

Hansen, Don, R and Maryanne M Mowen, 2007, Managerial Accounting, eight edition, Thompson South-Western Publishing, Mason, USA.

Hogan, John and Thomas Nagle, 2005, What Is Strategic Pricing?, www.strategicpricinggroup.com

Ireland; Hoskisson; Hitt. 2009. The Management of Strategy: Concept dan Cases. South Western, Cengange Learning 5191. Natorp Boulevard. Mason. USA.

Kiokue. 2012, Akuntansi: Strategi Penetapan Harga Strategis, Jurnal Ekonomi.

Kotler, Philip. et.al. 2009. Marketing Management, Thirteenth edition. Penerbit Erlangga.

Lansiluoto, et al, 2007, Strategic pricing Possibilities of Grocery Retailers - An empirical Study, The International Journal of Digital Accounting Research Vol. 7, N. 13-14, 2007, pp. 121- 152

Magdalena, Maria. 2010. Evaluasi Penentuan Harga Jual Produk Bakpia (Studi Kasus pada Bakpia Djogja). Skripsi Fakultas 
Ekonomi, Universitas Atmajaya Yogyakarta.

Micu, Adrian and Angela Micu, 2006, Strategic Pricing, Buletin University of Petrol, Vol.LVIII, No.2/2006.

Porter, Michael,1993, Strategi, Bersaing: Teknik Menganalisis Industri dan Pesaing. terjemahan oleh Agus Maulana, Penerbit Erlangga, Jakarta.
Suwarni. 2013. Marketing Mix Strategy dalam Meningkatkan Volume Penjualan. Jurnal Ekonomi. Fakultas Ekonomi Universitas Negeri Malang.

Strategic Edge, LLC,2008, Strategic Pricing for Industrial Products, www.stratedg.com

www.tempo.com, Indonesia Peringkat 5 Jumlah Penderita Diabetes, Jum'at, 14 November 2014 